\title{
Postoje žiakov 4. ročníka základných škôl v okrese Zvolen $k$ telesnej a športovej výchove
}

\section{Attitude of pupils $4^{\text {th }}$ class of primary schools for the physical and sport education}

\author{
Peter Mesiarik \\ Fakulta humanitných vied, Univerzita Mateja Bela, Banská Bystrica, Slovenská republika
}

\begin{abstract}
Abstrakt
V príspevku sú prezentované výsledky výskumu zameraného na zistenie postojov žiakov 4. ročníkov ZŠ v okrese Zvolen k telesnej a športovej výchove. Výskumný súbor tvorilo 553 žiakov z 8 mestských a 8 vidieckych základných škôl. Ako základný výskumný nástroj bol použitý štandardizovaný postojový dotazník určený pre žiakov 4. stupňa základnej školy. Autor zistil, že u chlapcov a dievčat prevažujú pozitívne a vel’mi pozitívne postoje $k$ telesnej a športovej výchove nad postojmi indiferentnými. Žiaci mestských základných škôl mali pozitívnejšie postoje ako žiaci dedinských základných škôl. Najviac indiferentných postojov k telesnej a športovej výchove prejavili žiaci na malotriednych dedinských základných školách, kde sú nevyhovujúce podmienky pre telesnú a športovú výchovu.
\end{abstract}

\section{Abstract}

This paper presents the results of research to determine attitudes of students 4thgrades of primary schools in the district Zvolen to physical and sport education. Research set consisted of 553 students from 8 urban and 8 village primary schools. As a basic research tool was a standardized questionnaire designed for attitudinal students first primary school. The authors found that boys and girls more positive and very positive attitudes toward physical and sport education over the indifferent attitudes. Students of urban primary schools had more positive attitudes than students of village primary schools. The most indifferent attitudes toward physical education for pupils showed low-class village primary schools, where are poor conditions for physical and sport education.

Kl'účové slová: postoje, telesná a športová výchova, základná škola.

Keywords: attitudes, physical and sport education, primary school.

\section{ÚVOD}

Telesná a športová výchova je svojim zameraním špecifický vyučovací predmet, pretože sa orientuje nielen na telesné, funkčné, pohybové, ale aj na psychické a rozumové zdokonal'ovanie žiakov a jedným z jeho hlavných ciel'ov je okrem iného aj formovat' u žiakov pozitívny postoj nielen k tomuto vyučovaciemu predmetu, ale aj k pohybovej aktivite a športu vôbec. Najúčinnejším prostriedkom formovania a upevňovania pozitívneho postoja k telesnej a športovej výchove je kvalitne vedený telovýchovný proces vyznačujúci sa všestrannost’ou, primeranou intenzitou, originálnost'ou a náležitou emocionálnostou.

Postoje patria do základného psychického uspôsobenia človeka. Človek sa s postojmi nerodí, ale vytvárajú sa na základe životnej skúsenosti. Každý jedinec si systém, alebo š truktúru postojov vytvára sám v sebe v priamej súčinnosti s l’ud'mi, spoločnost’ou, s jej inštitúciami. Napriek tomu, že postoje sú pomerne ustálené sústavy hodnotenia, predsa sa $\mathrm{v}$ živote človeka menia. V telovýchovnom procese zohráva dôležitú úlohu učitel' telesnej a športovej výchovy, ktorý svojou odbornost’ou a prístupom významne ovplyvňuje svojich žiakov k telesnej a športovej výchove ako aj k pohybovej aktivite a športu. Mnohokrát sa stane, že aj menej pohybovo zdatný žiak podá lepší výkon ako jeho technicky lepší spoluhráč. Rozdiel spočíva v postoji, t.j. v snahe, v bojovnosti, v nasadení pri plnení úloh. 
Postoje sú v psychológii definované ako relatívne trvalé sústavy pozitívnych, alebo negatívnych hodnotení, emocionálneho cítenia a tendencií konat' pre, alebo proti spoločenským objektom. Ako sme už uviedli človek sa s postojmi nerodí - postoje ako také nie sú človeku vrodené. Vytvárajú sa životnou skúsenost’ou, počnúc asi tretím - štvrtým rokom života (Kubáni, 2004).

Podl'a Boroša - Ondriškovej - Živčicovej (1999) sú postoje pomerne trvalé charakteristiky jednotlivca, ktoré vyjadrujú jeho stanovisko (pozitívne či negatívne) k určitej oblasti skutočnosti, vyjadrujú nielen základnú poznávaciu orientáciu, ale aj hodnotový systém človeka a jeho snahovú zameranost'. V tomto zmysle sú postoje faktorom, ktorý silne ovplyvňuje správanie sa jednotlivca. Objektom postoja môže byt' čokol'vek, čo človek registruje, alebo čím sa zaoberá v mysli. Predmety postojov môžu byt' konkrétne alebo abstraktné, predmetmi môžu byt' neživé veci, osoby alebo celé skupiny.

Nakonečný (1999) hovorí o postojoch ako o hodnotiacich vzt’ahoch, ktoré zakladajú určitú konatívnu pohotovost', ktorej realizácia v príslušnom konaní však závisí od situačných podmienok. Poliach (2003) uvádza, že postoje významne ovplyvňujú konanie v situáciách každodenného života. Uplatňujú sa všade tam, kde je dôležité a možné slobodné rozhodovanie (napr. nákupy, plánovanie vol'ného času, riešenie konfliktov ap.). Pojem postoj sa v iných disciplínach (napr. v sociológii, v ekonómii, v politológii) používa aj v širšom slova zmysle ako charakteristika celých skupín l'udí (napr. voličské postoje, zákaznícke postoje). Postoje sú taktiež v mnohom blízke osobným hodnotám a súvisia aj s vedomost’ami, skúsenost’ami a motiváciou.

Postoj je podl'a Hartla (2004) hodnotiaci vzt'ah vyjadrený sklonom reagovat' ustáleným spôsobom na predmety, osoby, situácie a na seba samého. Predurčujú poznanie, chápanie, myslenie a cítenie. Podobne podl'a Kosovej - Kasáčovej (2009) je postoj vzt’ah k niečomu. Ide o relatívne ustálené tendencie kladne, či záporne reagovat' na určité podnety. Vopred určuje naše správanie v situácií, obsahuje emotívne, hodnotiace aspekty, kognitívnu zložku a konatívnu - je pripravený konat'. Podl’a Bartíka (2007a) jeden z klúčcových výchovných ciel'ov povinného vyučovacieho predmetu telesná a športová výchova v novej koncepcii je formovanie vzt'ahu a reálneho aktívneho postoja žiakov $\mathrm{k}$ telesnej a športovej výchove a $\mathrm{k}$ vlastnému zdraviu. S jeho plnením sa má začínat' od prvých hodín telesnej a športovej výchovy už na 1. stupni základnej školy. Práve zanedbávanie a nevyužívanie emocionálnych a racionálnych komponentov tvoriacich nevyhnutnú podmienku pri napíňaní tohto ciel'a na 1. stupni ZŠ zapríčiňuje vo vyšších ročníkoch postupné oslabenie záujmu žiakov o pohyb i telesnú výchovu. V priebehu rastu mladého jedinca zohráva významnú úlohu sociálny vývoj a zmeny v sebahodnotení. Preto je vel'mi dôležité, aby si učitelia telesnej a športovej výchovy i športoví tréneri uvedomili, že športové a pohybové skúsenosti získané v období puberty, predovšetkým do 12. roku, môžu významne ovplyvnit’ postoje, ktoré mladý človek zaujme k pohybovej aktivite a športu vôbec (Dobrý, 2006).

Problematikou zist'ovania postojov žiakov k telesnej výchove na základných a stredných školách sa v minulosti zaoberali napr. Antala - Dorošová (1996), Görner - Starší (2001), Bartík (2005,2006,2007a, 2007b, 2009a, 2009b), Bartík - Mesiarik (2009, 2011), Ludvíková (2010a, 2010b, 2010c), Mesiarik (2009, 2010, 2011), Michal - Kollár - Kružliak (2010) a Palička (2011a, 2011b). V Českej republike to boli napr. Rýgl (2003a, 2003b), v Českej republike a v Pol’sku Górna (1997, 1998), Subramanian - Silverman (2007) na školách v USA, Stelzer - Ernest - Fenster - Langford (2004) na školách v Anglicku, Českej republike Rakúsku a USA. Postojmi študentov na slovenských vysokých školách sa zaoberal Šikula (1992), Michal (2002) a Pistlová - Sedláček (2008), na vysokých školách Sekot (2007b). U dospelej populácie v Českej republike napr. Zich - Ungr (1995) a Sekot (2007a).

Všeobecným ciel'om telesnej a športovej výchovy je umožnit' žiakom osvojit' si, zdokonal'ovat' a upevňovat' pohybové návyky a zručnosti na primeranej úrovni, zvyšovat' svoju pohybovú gramotnost', rozvíjat' kondičné a koordinačné schopnosti, zvyšovat' všeobecnú pohybovú výkonnost' a zdatnost', prostredníctvom vykonávanej pohybovej aktivity pôsobit' a dbat' o zdravie, vytvárat' trvalý vzt'ah k pohybovej aktivite, telesnej výchove a športu s ohl'adom na záujmy žiakov, ich predpoklady a individuálne potreby ako súčast' zdravého životného štýlu a predpokladu schopnosti celoživotnej starostlivosti o vlastné zdravie.

V súčasnej dobe sa v slovenskom školstve v duchu jeho reformy a v zmysle školského zákona č. 245/2008 uplatňuje dvojúrovňový participatívny model kurikula. Na štátnej úrovni je to tzv. štátne kurikulum obsiahnuté v štátnom vzdelávacom programe a na úrovni školy je to školské kurikulum rozpracované vo vlastnom školskom vzdelávacom programe.

Podl’a Mikuša - Bebčákovej - Modráka (2008) sa v oblasti kurikula pre základné a stredné školy uplatňuje dvojúrovňový participatívny model a to štátne kurikulum (Štátny vzdelávací program) a školské kurikulum (školské vzdelávacie programy). Zdôrazňujú zmenu hierarchie zložiek učiva k vytváraniu hodnôt, postojov, 
schopností, zručností a vedomostí. Ďalej uvádzajú nové trendy v riadení telovýchovného procesu na školách: od vyučovania $\mathrm{k}$ učeniu sa; od pasivity žiaka $\mathrm{k}$ aktivite, tvorivosti a prežívaniu; od autoritárstva a dogmatizmu k humanizácii vyučovania; od učitel'a ako neomylnej autority k učitel'ovi - poradcovi; od orientácie na priemerného žiaka k diferencovanému a individuálnemu prístupu k žiakovi; od hromadnej práce žiakov k práci skupinovej; od dôrazu na obsah učiva k dôrazu na celý vyučovací proces.

Vyučovací predmet telesná a športová výchova by sa mala podiel'at' najmä na rozvíjaní pohybových, kognitívnych, komunikatívnych, učebných, interpersonálnych a postojových predmetových kompetencií (Bebčáková et al., 2009). Rozvíjanie postojových kompetencií by malo byt' zamerané najmä na to, aby žiak mal zážitok z vykonávanej pohybovej činnosti, dokázal zvít’azit', ale i prijat' prehru v športovom zápolení i v živote, aby uznal kvality súpera, dodržiaval princípy fair-play, zapájal sa do mimoškolskej telovýchovnej a športovej aktivity, využíval poznatky, skúsenosti a zručnosti z oblasti telesnej výchovy a športu a iných predmetov so zameraním na zdravý spôsob života a ochranu prírody.

Na druhej strane súhlasíme s Hercigom (2009), ktorý zdôrazňuje, že telesná výchova bola a mnohokrát stále je na okraji záujmu verejnosti i pedagogického zboru a vedenia škôl, je potrebné implementáciu telesnej a športovej výchovy do školských vzdelávacích programov podporovat'. Z jeho pohl'adu je dôležitá podpora a realizácia didaktického procesu a podpora monitoringu a diagnostiky, čo je aj ciel’om našej práce.

\section{METODIKA}

Výskumný súbor tvorili žiaci 4. ročníkov všetkých šestnástich základných škôl v okrese Zvolen. Celkove bolo do výskumu zapojených 8 mestských a 8 vidieckych základných škôl. Celkový počet respondentov bol 553 (Tabul'ka 1) a upotrebitel'nost' dotazníkov bola 95,34 \%. Všetkých 8 mestských základných škôl bolo plneorganizovaných. Z ôsmich vidieckych základných škôl bolo 5 plneorganizovaných a 3 boli organizované iba pre 1. stupeň (malotriedne). Výskum sme realizovali v šk. roku 2011/2012 v mesiaci február 2012.

Tabul'ka 1 - Zloženie výskumnej vzorky žiakov

\begin{tabular}{|l|c|c|c|c|}
\hline \multirow{2}{*}{ Pohlavie žiakov } & \multirow{2}{*}{ Mestské ZŠ } & \multicolumn{2}{|c|}{ Vidiecke ZŠ } & \multirow{2}{*}{ Spolu } \\
\cline { 3 - 4 } & & Plneorganizované & Malotriedne & \\
\hline Chlapci & 217 & 51 & 17 & 285 \\
& $51,06 \%$ & $51,51 \%$ & $58,62 \%$ & $50,77 \%$ \\
\hline Dievčatá & 208 & 48 & 12 & 268 \\
& $48,94 \%$ & $48,49 \%$ & $41,38 \%$ & $49,23 \%$ \\
\hline Spolu & 425 & 99 & 29 & 553 \\
& $76,85 \%$ & $17,90 \%$ & $5,25 \%$ & $100 \%$ \\
\hline
\end{tabular}

Výber metód v danom výskume sme sa snažili vykonat’ tak, aby nám jednotlivé použité metódy poskytli podl'a možností čo najviac kvalitných údajov pre analýzu daného problému a komparáciu výsledkov s inými výskumnými prácami v predmetnej oblasti skúmania. Pri použití výskumných metód vo výskume sme sa pridŕžali zásad a odporúčaní, ktoré uvádzajú Starší - Görner (1995), Katuščák (1998), Švec et al. (1998), Starší (1999), Sivák et al. (2000), Görner - Starší (2001), Lászlo (2003) a Mikuš - Bebčáková et al. (2004).

Hlavnou výskumnou metódou pri získavaní faktografického materiálu bol štandardizovaný postojový dotazník určený pre žiakov 4. ročníkov základných škôl podl’a Sivák - Kršjaková - Sokol (2001), ale autori ho odporúčajú použit’ aj žiakom nižších ročníkov ZŠ (Príloha). Uvedený dotazník je rozdelený na tri dimenzie, kde každá obsahuje šest' položiek - výrokov (otázok), ktoré monitorujú kognitívnu, emotívnu a konatívnu zložku postoja. Žiaci vyjadrovali svoje stanovisko ku každej položke. 
Kvalita celkového postoja sa vyjadruje nasledovne:
$0-7$ bodov vel'mi negatívny postoj
$8-14$ bodov negatívny postoj
$15-22$ bodov
$23-28$ bodov indiferentný postoj
$29-36$ bodov pozitívny postoj vel'mi pozitívny postoj

K jednotlivým zložkám postoja (kognitívna, emotívna, konatívna) je hodnotenie postoja nasledovné:
$0-2$ body
$3-5$ bodov
vel'mi negatívny postoj
$6-7$ bodov negatívny postoj
$8-9$ bodov indiferentný postoj
$10-12$ bodov
pozitívny postoj
vel'mi pozitívny postoj

Pri hodnotení orientácie a úrovne postojov k telesnej a športovej výchove sme kvalitu úrovne postojov vyjadrili v bodoch. V prvej etape vyhodnocovania a spracovania faktografického materiálu sme využili najmä základné matematicko - štatistické metódy, sumarizáciu údajov, aritmetický priemer, percentuálne výpočty a vyjadrenia, maximálna hodnota, minimálna hodnota, ai.

Pri interpretácii výsledkov výskumu sme použili tabul'ky a grafy vo forme obrázkov. Pri vyhodnocovaní údajov získaných štatistickým spracovaním a v rámci vyhodnotenia kvalitatívnych údajov sme použili analyticko-syntetické a induktívno-deduktívne metódy - analýzu, syntézu, indukciu, dedukciu a porovnávanie (komparáciu).

\section{VÝSLEDKY}

Výsledky výskumu a prehl’ad o orientácii postojov žiakov 4. ročníkov k telesnej a športov ej výchove na mestských (8) a vidieckych (8) základných školách v Okrese Zvolen pre lepšiu prehl'adnost’ uvádzame v Tabul'ke 2 a na Obrázku 1.

Tabul'ka 2 - Postoje žiakov 4. ročníkov mestských a vidieckych ZŠ v okrese Zvolen k telesnej a športovej výchove

\begin{tabular}{|c|c|c|c|c|c|c|c|c|}
\hline \multirow[t]{3}{*}{ Postoj } & \multirow{2}{*}{\multicolumn{2}{|c|}{$\begin{array}{c}\text { Mestské Ž̌ } \\
\text { (8) }\end{array}$}} & \multicolumn{4}{|c|}{ Vidiecke ZŠ (8) } & \multirow{2}{*}{\multicolumn{2}{|c|}{$\begin{array}{c}\text { Spolu } \\
\text { (všetky ZŠ) }\end{array}$}} \\
\hline & & & \multicolumn{2}{|c|}{$\begin{array}{c}\text { Plneorganizované } \\
(5)\end{array}$} & \multicolumn{2}{|c|}{$\begin{array}{c}\text { Malotriedne } \\
\text { (3) }\end{array}$} & & \\
\hline & Počet & $\%$ & Počet & $\%$ & Počet & $\%$ & Počet & $\%$ \\
\hline Vel'mi pozitívny & 143 & $33,65 \%$ & 30 & $30,30 \%$ & 5 & $17,24 \%$ & 178 & $32,19 \%$ \\
\hline Pozitívny & 216 & $50,82 \%$ & 50 & $50,50 \%$ & 9 & $31,03 \%$ & 275 & $49,74 \%$ \\
\hline Indiferentný & 59 & $13,89 \%$ & 19 & $19,20 \%$ & 13 & $44,84 \%$ & 91 & $16,45 \%$ \\
\hline Negatívny & 5 & $1,17 \%$ & - & - & 2 & $6,89 \%$ & 7 & $1,26 \%$ \\
\hline Vel'mi negatívny & 2 & $0,47 \%$ & - & - & - & - & 2 & $0,36 \%$ \\
\hline Spolu & 425 & $100 \%$ & 99 & $100 \%$ & 29 & $100 \%$ & 553 & $100 \%$ \\
\hline
\end{tabular}


Obrázok 1 - Postoje žiakov 4. ročníkov mestských a vidieckych ZŠ v okrese Zvolen k telesnej a športovej výchove

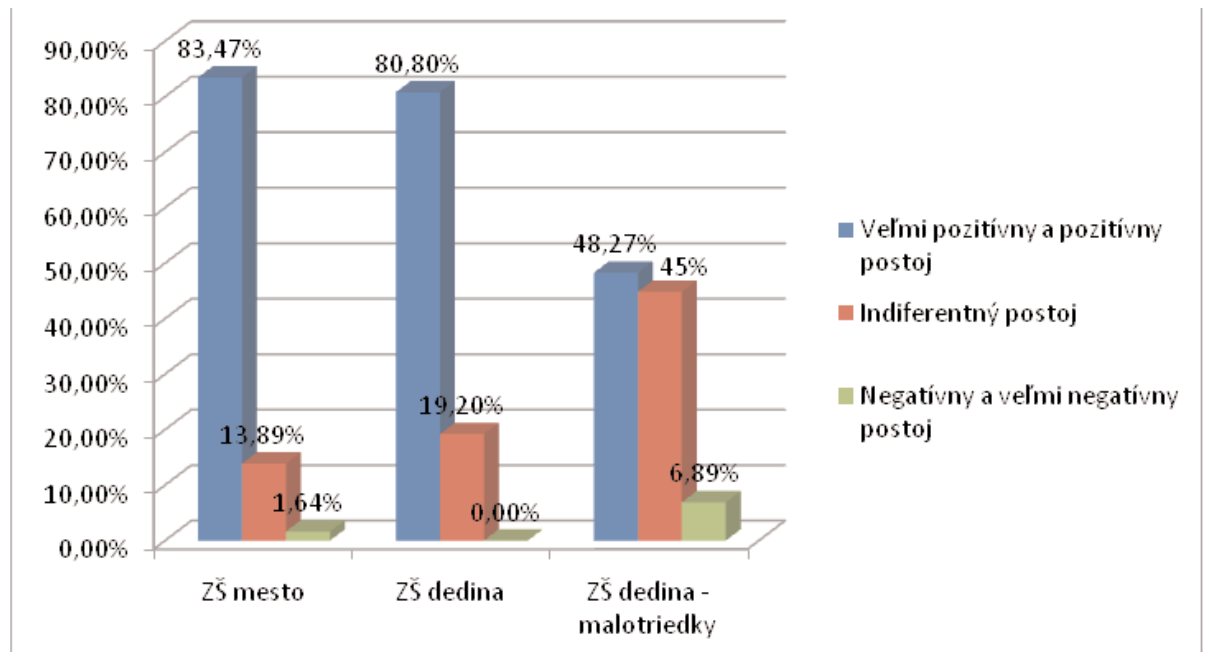

Z 553 respondentov (285 chlapcov a 268 dievčat) 4. ročníkov šestnástich základných škôl v okrese Zvolen prejavilo k telesnej a športovej výchove vel'mi pozitívny postoj 178 resp ondentov - 32,19\% a pozitívny postoj 275 respondentov $-49,74 \%$, čo predstavuje spolu 453 respondentov - 81,93\%. Indiferentný postoj prejavilo iba 91 respondentov $-16,45 \%$.Negatívny postoj prejavilo iba 7 respondentov $-1,26 \%$ a vel'mi negatívny postoj iba 2 respondenti - $0,36 \%$, čo sú zanedbatel'né počty žiakov.

Pri porovnaní výsledkov mestských ZŠ s vidieckymi ZŠ v okrese Zvolen (Tabul'ka 2) môžeme vidiet' rozdiely $\mathrm{v}$ orientácii postojov $\mathrm{k}$ telesnej a športovej výchove. Najviac pozitívnych a vel’mi pozitívnych postojov prejavili žiaci na mestských Z $\breve{S}-84,47$ \%, čo je o 3,67 \% menej ako žiaci na vidieckych plneorganizovaných ZŠ $-80,80 \%$ a naopak najmenej žiakov prejavilo pozitívne a vel'mi pozitívne postoje na vidieckych malotriednych Z $\breve{S} \neg 48,27$ \%. Znepokojujúce je zistenie na vidieckych malotriednych ZŠ, kde žiaci 4. ročníkov prejavili až 44,84 indiferentných postojov a 6,89 \% negatívnych postojov. Príčinou týchto výsledkov na malotriednych ZŠ je najmä to, že všetky tri takéto ZŠ mali nedostatočné materiálne a priestorové vybavenie pre realizáciu telesnej a športovej výchovy. Ani jedna z týchto škôl nedisponovala telocvičňou a dostatočne priestrannými vonkajšími ihriskami a telesná a športová výchova a športové záujmové krúžky sa realizovali vo väčších upravených učebniach, na chodbách škôl a od jari do jesene aj v prírodnom prostredí.

U samostatných skupín chlapcov a dievčat 4. ročníkov sme dosiahli obdobné výsledky ako u všetkých žiakov a uvádzame ich v Tabul'ke 3 (chlapci) a v Tabul'ke 4 (dievčatá).

Tabul'ka 3 - Postoje chlapcov 4. ročnikov mestských a vidieckych ZŠ v okrese Zvolen k telesnej a športovej výchove

\begin{tabular}{|c|c|c|c|c|c|c|c|c|}
\hline \multirow[t]{3}{*}{ Postoj } & \multirow{2}{*}{\multicolumn{2}{|c|}{$\begin{array}{c}\text { Mestské ZŠ } \\
\text { (8) }\end{array}$}} & \multicolumn{4}{|c|}{ Vidiecke ZŠ (8) } & \multirow{2}{*}{\multicolumn{2}{|c|}{$\begin{array}{c}\text { Spolu } \\
\text { (všetky Zك̌s) }\end{array}$}} \\
\hline & & & \multicolumn{2}{|c|}{$\begin{array}{l}\text { Plneorganizované } \\
\text { (5) }\end{array}$} & \multicolumn{2}{|c|}{$\begin{array}{l}\text { Malotriedne } \\
\text { (3) }\end{array}$} & & \\
\hline & Počet & $\%$ & Počet & $\%$ & Počet & $\%$ & Počet & $\%$ \\
\hline Vel'mi pozitívny & 84 & $38,70 \%$ & 16 & $31,37 \%$ & 3 & $17,65 \%$ & 103 & $36,14 \%$ \\
\hline Pozitívny & 109 & $50,25 \%$ & 27 & $52,94 \%$ & 4 & $23,53 \%$ & 140 & $49,13 \%$ \\
\hline Indiferentný & 23 & $10,59 \%$ & 8 & $15,69 \%$ & 8 & $47,06 \%$ & 39 & $13,68 \%$ \\
\hline Negatívny & 1 & $0,46 \%$ & - & - & 2 & $11,76 \%$ & 3 & $1,05 \%$ \\
\hline Vel'mi negatívny & - & - & - & - & - & - & - & - \\
\hline Spolu & 217 & $100 \%$ & 51 & $100 \%$ & 17 & $100 \%$ & 285 & $100 \%$ \\
\hline
\end{tabular}


Tabul'ka $4 \neg$ Postoje dievčat 4. ročníkov mestských a vidieckych ZŠ v okrese Zvolen k telesnej a športovej výchove

\begin{tabular}{|c|c|c|c|c|c|c|c|c|}
\hline \multirow[t]{3}{*}{ Postoj } & \multirow{2}{*}{\multicolumn{2}{|c|}{$\begin{array}{c}\text { Mestské ZŠ } \\
\text { (8) }\end{array}$}} & \multicolumn{4}{|c|}{ Vidiecke ZŠ (8) } & \multirow{2}{*}{\multicolumn{2}{|c|}{$\begin{array}{c}\text { Spolu } \\
\text { (všetky Zك̌) }\end{array}$}} \\
\hline & & & \multicolumn{2}{|c|}{$\begin{array}{l}\text { Plneorganizované } \\
\text { (5) }\end{array}$} & \multicolumn{2}{|c|}{$\begin{array}{c}\text { Malotriedne } \\
\text { (3) }\end{array}$} & & \\
\hline & Počet & $\%$ & Počet & $\%$ & Počet & $\%$ & Počet & $\%$ \\
\hline Vel'mi pozitívny & 58 & $27,89 \%$ & 14 & $29,16 \%$ & 2 & $16,68 \%$ & 74 & $27,61 \%$ \\
\hline Pozitívny & 103 & $49,52 \%$ & 23 & $47,91 \%$ & 5 & $41,66 \%$ & 131 & $48,89 \%$ \\
\hline Indiferentný & 41 & $19,71 \%$ & 11 & $22,93 \%$ & 5 & $41,66 \%$ & 57 & $21,27 \%$ \\
\hline Negatívny & 4 & $1,62 \%$ & - & - & - & - & 4 & $1,49 \%$ \\
\hline Vel'mi negatívny & 2 & $0,96 \%$ & - & - & - & - & 2 & $0,74 \%$ \\
\hline Spolu & 208 & $100 \%$ & 48 & $100 \%$ & 12 & $100 \%$ & 268 & $100 \%$ \\
\hline
\end{tabular}

Porovnaním výsledkov uvedených v Tabul'ke 3 (chlapci) a v Tabul'ke 4 (dievčatá) môžeme vidiet', že chlapci mestských $(88,95 \%)$ a vidieckych $(84,31 \%)$ ZŠ mali viac vel'mi pozitívnych a pozitívnych postojov ako dievčatá na mestských $(77,41 \%)$ a vidieckych ZŠ $(73,32)$. Naopak na malotriednych vidieckych ZŠ mali viac vel'mi pozitívnych a pozitívnych postojov dievčatá $(58,34 \%)$ ako chlapci $(41,18 \%)$.

\section{Poznávacia, emotívna a konatívna zložka postoja}

Pri skúmaní jednotlivých dimenzií postoja sme u žiakov 4. ročníkov ZŠ v okrese Zvolen zistili v poznávacej, emotívnej a konatívnej zložke postoja prevahu pozitívnych a vel'mi pozitívnych postojov nad postojmi indiferentnými a zanedbatel'né množstvo negatívnych a vel'mi negatívnych postojov k telesnej a športovej výchove, ktoré prezentujeme v Tabul'ke 5.

Tabul'ka 5 - Porovnanie kvality postojov žiakov (chlapcov a dievčat) 4. ročníkov mestských a vidieckych ZŠ v okrese Zvolen (vrátane malotriednych ZŠ) k telesnej a športovej výchove-poznávacia, emotívna a konatívna zložka postoja

\begin{tabular}{|c|c|c|c|c|c|c|c|c|c|c|c|c|}
\hline \multirow{3}{*}{$\begin{array}{l}\text { Postoj } \\
\text { žiakov }\end{array}$} & \multicolumn{6}{|c|}{ Mestské ZŠ } & \multicolumn{6}{|c|}{ Dedinské ZS̆ } \\
\hline & \multicolumn{2}{|c|}{ Pozn. zlož. } & \multicolumn{2}{|c|}{ Emot. zlož. } & \multicolumn{2}{|c|}{ Kon. zlož. } & \multicolumn{2}{|c|}{ Pozn. zlož. } & \multicolumn{2}{|c|}{ Emot. zlož. } & \multicolumn{2}{|c|}{ Kon. zlož. } \\
\hline & Počet & $\%$ & Počet & $\%$ & Počet & $\%$ & Počet & $\%$ & Počet & $\%$ & Počet & $\%$ \\
\hline VP & 138 & 32,47 & 174 & 40,96 & 134 & 31,53 & 40 & 31,25 & 37 & 28,90 & 42 & 32,81 \\
\hline $\mathrm{P}$ & 200 & 7 & 176 & 41,41 & 198 & 46 & 59 & 46 & 60 & 46,89 & 59 & 46,09 \\
\hline I & 68 & 16,00 & 54 & 12,70 & 63 & 14,82 & 26 & 20,32 & 27 & 21,09 & 26 & 20,32 \\
\hline $\mathrm{N}$ & 16 & 3,76 & 18 & 4,23 & 23 & 5,41 & 1 & 0,78 & 3 & 2,34 & 1 & 0,78 \\
\hline VN & 3 & 0,70 & 3 & 0,70 & 7 & 1,65 & 2 & 1,56 & 1 & 0,78 & - & - \\
\hline Spolu & 425 & 100 & 425 & 100 & 425 & 100 & 128 & 100 & 128 & 100 & 128 & 100 \\
\hline
\end{tabular}

$\mathrm{Na}$ mestských ZŠ mali žiaci najviac indiferentných postojov (16 \%) v poznávacej zložke postoja. $\mathrm{Na}$ vidieckych ZŠ mali najviac indiferentných postojov žiaci v emotívnej zložke postoja (21,09 \%), avšak iba o niečo menej mali zhodne v poznávacej a konatívnej zložke postoja (20,32 \%). Učitelia telesnej a športovej výchovy na mestských ZŠ by sa mali zamerat' počas vyučovania okrem rozvíjania emotívnej a konatívnej zložky postoja aj na poznávaciu zložku postoja a viac so žiakmi komunikovat' a vysvetl'ovat' im dôležitost', obsah a význam cvičení. Na vidieckych ZŠ sú u žiakov rezervy vo všetkých troch zložkách postoja a preto by sa učitelia na predmete telesná a športová výchova mali zamerat' okrem rozvoja konatívnej zložky postoja (ako učitelia na mestských ZŠ) aj na rozvoj emotívnej a kognitívnej zložky postoja. To znamená, že by mali vyberat' pre žiakov také cvičenia, pohybové a športové aktivity, ktoré by ich viac oslovili a zaujali a vykonávali ich s radost'ou. Dôležité je aj modernizovat' obsah vyučovania podl'a záujmov žiakov a používat' širšie spektrum foriem a metód práce. V Tabul'ke 6 prinášame výsledky chlapcov a dievčat 4. ročníkov mestských ZŠ a v Tabul'ke 7 výsledky chlapcov a dievčat 4. ročníkov vidieckych ZŠ v konatívnej, emotívnej a kognitívnej zložke postoja. 
Tabul'ka 6 - Kognitívna, emotívna a konatívna zložka postoja k telesnej a športovej výchove u žiakov 4. ročníkov mestských ZŠ v okrese Zvolen

\begin{tabular}{|l|c|c|c|c|c|c|}
\hline \multirow{2}{*}{$\begin{array}{l}\text { Postoj } \\
\text { žiakov }\end{array}$} & \multicolumn{3}{|c|}{ Chlapci a dievčatá 4. ročníkov mestských ZŠ v okrese Zvolen (8ZŠ) } \\
\cline { 2 - 7 } & $\begin{array}{c}\text { kognitívna } \\
\text { zložka }\end{array}$ & $\begin{array}{c}\text { emotívna } \\
\text { zložka }\end{array}$ & $\begin{array}{c}\text { konatívna } \\
\text { zložka }\end{array}$ & $\begin{array}{l}\text { kognitívna } \\
\text { zložka }\end{array}$ & $\begin{array}{l}\text { emotívna } \\
\text { zložka }\end{array}$ & $\begin{array}{l}\text { konatívna } \\
\text { zložka }\end{array}$ \\
\cline { 2 - 7 } & $\begin{array}{c}\text { Počet } \\
\%\end{array}$ & $\begin{array}{c}\text { Počet } \\
\%\end{array}$ & $\begin{array}{c}\text { Počet } \\
\%\end{array}$ & $\begin{array}{c}\text { Počet } \\
\%\end{array}$ & $\begin{array}{c}\text { Počet } \\
\%\end{array}$ & $\begin{array}{c}\text { Počet } \\
\%\end{array}$ \\
\hline Vel'mi poz. & 81 & 105 & 71 & 57 & 69 & 63 \\
& $37,32 \%$ & $48,40 \%$ & $32,72 \%$ & $27,40 \%$ & $33,17 \%$ & $30,29 \%$ \\
\hline Pozitívny & 102 & 84 & 103 & 98 & 92 & 95 \\
& $47,02 \%$ & $28,70 \%$ & $47,47 \%$ & $47,13 \%$ & $44,24 \%$ & $45,67 \%$ \\
\hline Indiferentný & 25 & 21 & 38 & 43 & 33 & 34 \\
& $11,52 \%$ & $9,67 \%$ & $17,51 \%$ & $20,67 \%$ & $15,86 \%$ & $16,35 \%$ \\
\hline Negatívny & 8 & 7 & 5 & 8 & 11 & 12 \\
& $3,68 \%$ & $3,23 \%$ & $2,30 \%$ & $3,84 \%$ & $5,29 \%$ & $5,77 \%$ \\
\hline Vel'mi neg. & 1 & - & - & 2 & 3 & 4 \\
& $0,46 \%$ & & & $0,96 \%$ & $1,44 \%$ & $1,62 \%$ \\
\hline Spolu & 217 & 217 & 217 & 208 & 208 & 208 \\
\hline
\end{tabular}

Tabul'ka 7 - Kognitívna, emotívna a konatívna zložka postoja k telesnej a športovej výchove žiakov 4. ročnikov vidieckych Ž̌ v okrese Zvolen

\begin{tabular}{|l|c|c|c|c|c|c|}
\hline \multirow{3}{*}{$\begin{array}{l}\text { Postoj } \\
\text { žiakov }\end{array}$} & \multicolumn{5}{|c|}{ Chlapci a dievčatá 4. ročníkov vidieckych ZŠ (5 ZŠ) } \\
\cline { 2 - 7 } & $\begin{array}{c}\text { kognitívna } \\
\text { zložka }\end{array}$ & $\begin{array}{c}\text { emotívna } \\
\text { zložka }\end{array}$ & $\begin{array}{c}\text { konatívna } \\
\text { zložka }\end{array}$ & $\begin{array}{l}\text { kognitívna } \\
\text { zložka }\end{array}$ & $\begin{array}{l}\text { emotívna } \\
\text { zložka }\end{array}$ & $\begin{array}{l}\text { konatívna } \\
\text { zložka }\end{array}$ \\
\cline { 2 - 7 } & $\begin{array}{c}\text { Počet } \\
\%\end{array}$ & $\begin{array}{c}\text { Počet } \\
\%\end{array}$ & $\begin{array}{c}\text { Počet } \\
\%\end{array}$ & $\begin{array}{c}\text { Počet } \\
\%\end{array}$ & $\begin{array}{c}\text { Počet } \\
\%\end{array}$ & $\begin{array}{c}\text { Počet } \\
\%\end{array}$ \\
\hline Vel'mi poz. & 20 & 16 & 19 & 15 & 15 & 13 \\
& $39,22 \%$ & $31,37 \%$ & $37,25 \%$ & $31,25 \%$ & $31,25 \%$ & $27,08 \%$ \\
\hline Pozitívny & 23 & 28 & 25 & 24 & 22 & 22 \\
& $45,10 \%$ & $54,90 \%$ & $49,02 \%$ & $50,00 \%$ & $45,84 \%$ & $45,84 \%$ \\
\hline Indiferentný & 8 & 7 & 7 & 9 & 11 & 13 \\
& $15,68 \%$ & $13,73 \%$ & $13,73 \%$ & $18,75 \%$ & $22,91 \%$ & $27,08 \%$ \\
\hline Negatívny & - & - & - & - & - & - \\
\hline Vel'mi neg. & - & - & - & - & - & - \\
\hline Spolu & 51 & 51 & 51 & 48 & 48 & 48 \\
\hline
\end{tabular}

Na základe analýzy výsledkov uvedených v Tabul'ke 6 môžeme povedat', že chlapci na mestských ZŠ majú najviac indiferentných postojov v konatívnej zložke postoja, dievčatá zas v kognitívnej zložke postoja. Na základe analýzy výsledkov prezentovaných v Tabul'ke 7 môžeme povedat', že chlapci na vidieckych ZŠ majú najviac indiferentných postojov v kognitívnej (poznávacej) zložke postoja, dievčatá zas v konatívnej zložke postoja.

Dievčatá zaostávajú za chlapcami na mestských aj vidieckych ZŠ najmä v emotívnej a konatívnej zložke postoja, čo znamená, že učitelia v telesnej a športovej výchove by sa mali zamerat' u dievčat na výber vhodnejších cvičení, pohybových aktivít a športov, ktoré by ich zaujali, viac motivovali a mali z nich pozitívnejšie pocity. Rezervy sú však aj u skupiny chlapcov a priestor na skvalitňovanie hodín telesnej a športovej výchovy je aj u tejto skupiny žiakov. Ked’že na 1. stupni ZŠ, kde patria aj žiaci 4. ročníka je koedukovaná výuka o to je táto úloha pre učitel'ov náročnejšia a zložitejšia.

V Tabul'ke 8 prinášame výsledky na malotriednych vidieckych ZŠ, kde dievčatá mali viac indiferentných postojov vo všetkých troch zložkách postoja ako chlapci. 
Tabul'ka 8 - Kognitívna, emotívna a konatívna zložka postoja k telesnej a športovej výchove žiakov 4. ročníkov vidieckych malotriednych ZŠ v okrese Zvolen

\begin{tabular}{|l|c|c|c|c|c|c|}
\hline \multirow{3}{*}{$\begin{array}{l}\text { Postoj } \\
\text { žiakov }\end{array}$} & \multicolumn{5}{|c|}{ Chlapci a dievčatá 4. ročníkov malotriednych vidieckych ZŠ (3) } \\
\cline { 2 - 7 } & \multicolumn{5}{|c|}{ Chlapci } & \multicolumn{3}{c|}{ Dievčatá } \\
\cline { 2 - 7 } & $\begin{array}{c}\text { kognitívna } \\
\text { zložka }\end{array}$ & $\begin{array}{c}\text { emotívna } \\
\text { zložka }\end{array}$ & $\begin{array}{c}\text { konatívna } \\
\text { zložka }\end{array}$ & $\begin{array}{l}\text { kognitívna } \\
\text { zložka }\end{array}$ & $\begin{array}{l}\text { emotívna } \\
\text { zložka }\end{array}$ & $\begin{array}{l}\text { konatívna } \\
\text { zložka }\end{array}$ \\
\cline { 2 - 7 } & $\begin{array}{c}\text { Počet } \\
\%\end{array}$ & $\begin{array}{c}\text { Počet } \\
\%\end{array}$ & $\begin{array}{c}\text { Počet } \\
\%\end{array}$ & $\begin{array}{c}\text { Počet } \\
\%\end{array}$ & $\begin{array}{c}\text { Počet } \\
\%\end{array}$ & $\begin{array}{c}\text { Počet } \\
\%\end{array}$ \\
\hline Vel'mi poz. & 4 & 3 & 3 & 1 & 3 & 5 \\
& $23,53 \%$ & $17,65 \%$ & $17,65 \%$ & $8,33 \%$ & $25,00 \%$ & $41,67 \%$ \\
\hline Pozitívny & 6 & 7 & 7 & 6 & 3 & 5 \\
& $35,30 \%$ & $41,18 \%$ & $41,18 \%$ & $50,00 \%$ & $25,00 \%$ & $41,67 \%$ \\
\hline Indiferentný & 5 & 4 & 4 & 4 & 5 & 2 \\
& $29,41 \%$ & $23,53 \%$ & $23,53 \%$ & $33,34 \%$ & $41,67 \%$ & $16,66 \%$ \\
\hline Negatívny & 1 & 2 & 2 & - & 1 & - \\
& $5,88 \%$ & $11,76 \%$ & $11,76 \%$ & & $8,33 \%$ & - \\
\hline Vel'mi neg. & 1 & 1 & 1 & 1 & - & - \\
& $5,88 \%$ & $5,88 \%$ & $5,88 \%$ & $8,33 \%$ & & 12 \\
\hline Spolu & 17 & 17 & 17 & 12 & 12 & \\
\hline
\end{tabular}

Chlapci podobne ako dievčatá z malotriednych ZŠ v okrese Zvolen zaostávajú vo všetkých troch zložkách postoja za žiakmi plneorganizovaných vidieckych a mestských ZŠ a prejavili najviac indiferentných postojov vo všetkých troch zložkách postoja. U dievčat a chlapcov na malotriednych ZŠ je potrebné, aby sa učitelia, ktorí vyučujú TŠV zamerali na všetky tri zložky postoja. U dievčat je potrebné sa zamerat' najmä na emotívnu zložku postoja a u chlapcov najmä na kognitívnu zložku postoja, kde tieto skupiny žiakov prejavil najviac indiferentných postojov.

\section{DISKUSIA}

U žiakov 4. ročníka základných škôl v okrese Zvolen sme zistili prevahu vel'mi pozitívnych a pozitívnych postojov k telesnej a športovej výchove nad postojmi indiferentnými a postojmi negatívnymi. Podobné výsledky zistil u žiakov 1. stupňa na ZŠ v rôznych častiach Slovenska vo svojich výskumoch aj Bartík (2006, 2007a, 2009b), ked' v realizovanom výskume napr. v roku 2006 vel'mi pozitívny a pozitívny postoj k TV vyjadrilo 72,35 \% žiakov, indiferentný postoj zaujalo 26,4 \% žiakov a negatívny postoj prezentovalo iba 1,17 \% žiakov. Prevahu pozitívnych postojov nad postojmi indiferentným a postojmi negatívnymi zistili na 2 . stupni základných škôl v rôznych častiach Slovenska Bartík - Mesiarik (2011), Ludvíková (2010a, 2010b, 2010c), Mesiarik (2010, 2011) a Palička (2011a, 2011b).

Ďalšie výskumy, ktoré sme uviedli v tejto práci Rýgl (2003a), Bartík (2005, 2006, 2007 b, 2007 c, 2009), Vladovičová - Novotná (2005), Bartík - Mesiarik (2009) a Mesiarik (2009) poukázali všeobecne u chlapcov a dievčat na druhom stupni základných škôl už aj na nárast indiferentných postojov k telesnej a športovej výchove. Na niektorých školách v rámci vykonaných výskumov bola zistená u žiakov prevaha indiferentných postojov nad postojmi pozitívnymi. Bartík - Mesiarik (2009) a Mesiarik (2009) zistili u žiakov 2. stupňa základných školy prevahu indiferentných postojov nad postojmi pozitívnymi.

Výsledky výskumov mnohých autorov taktiež hovoria o tom, že deti z 1. stupňa základných škôl vykazujú pozitívnejšie postoje ako deti na 2 . stupni, čo pripisujeme najmä tomu, že u detí na 1 . stupni sa ešte prejavuje prirodzená hravost' a na druhej strane deti na druhom stupni majú širšie spektrum možností využitia vol'ného času najmä pasívnymi aktivitami (počítač, počítačové hry, komunikácia prostredníctvom internetu, mobil, chatovanie, SMS-kovanie).

Z hl'adiska vplyvu pohlavia na kvalitu a orientáciu postojov k telesnej a športovej výchove sme zistili, že chlapci na ZŠ v okrese Zvolen prejavili v postojovom dotazníku pozitívnejšie postoje k telesnej a športovej výchove ako dievčatá. Väčšina výsledkov výskumov taktiež hovorí o pozitívnejších postojoch k telesnej a športovej výchove u chlapcov v porovnaní s dievčatami. Vo svojich výskumoch to zistili aj Bartík (2006, 2007a, 2007b, 2009a, 2009b), ked' napríklad v realizovanom výskume v r. 2006 79,22 \% chlapcov vyjadrilo pozitívny postoj k školskej TV a športu, zatial čo dievčatá iba v 66,66 \%. Uvedené výsledky potvrdzujú aj výskumy autorov Bartík - Mesiarik (2009, 2011), Ludvíková (2010a, 2010b, 2010c), Mesiarik (2009, 2010, 
2011) a Palička (2011a, 2011b).

V súlade s inými autormi zastávame názor, že prevaha pozitívnejších postojov u chlapcov je podmienená najmä širšou a rozmanitejšou ponukou pohybových a športových aktivít ako na hodinách telesnej a športovej výchovy, tak aj v záujmovej školskej telesnej výchove a v športe na ZŠ v okrese Zvolen, ako zistil napr. aj Mesiarik (2010). Rodová rozdielnost' postojov k telesnej a športovej výchove je určená najmä historickým vývojom športu v spoločnosti, ked’ šport už v starom Grécku bol určený iba pre mužov a až v neskoršom vývoji spoločnosti sa šport dostáva aj medzi ženy. Výraznejšie zapojenie ženského pohlavia do pohybových a športových aktivít môžeme vidiet' až v 20. storočí, najmä $v$ jeho poslednej tretine. V súčasnej dobe môžeme vidiet' sút'aže ženského pohlavia aj v športoch donedávna určených výhradne iba pre mužov ako je napríklad futbal, či l'adový hokej.

Podl’a Šimoneka (2010) Ministerstvo školstva, vedy, výskumu a športu Slovenskej republiky pri predkladaní nového Školského zákona (Zákon o výchove a vzdelávaní č. 245/2008), ktorý dnes už platí štvrtý rok, proklamovalo, že v tomto záväznom školskom dokumente podporilo oblast' Zdravie a pohyb tým spôsobom, že popri 2 povinných hodinách telesnej a športovej výchovy zaviedlo možnost' d’alších hodín TŠV v rámci školského vzdelávacieho programu. Výsledky prieskumu však nepotvrdili túto skutočnost’ a až 83,33 \% škôl v mestách a 88,24 \% škôl na vidieku nezvýšilo popri povinných 2 hodinách počet hodín TŠV. Iba niečo vyše 16 \% mestských a necelých 12 \% vidieckych škôl využilo túto možnost’ a pridalo 1 hodinu TŠV za týždeň.

Povinná školská telesná a športová výchova v súčasnom rozsahu týždenného (na väčšine škôl 2 hodine týždenne), mesačného, či ročného počtu hodín je nedostatočná a preto vo vytváraní pozitívnych postojov k školskej telesnej výchove a športu, ale aj k pohybu a športu ako celoživotnej aktivite vôbec má nezastupitel'nú úlohu okrem iných činností a aktivít aj nepovinná, či záujmová školská telesná výchova a šport. Dve vyučovacie hodiny týždenne v povinnej školskej telesnej a športovej výchove na väčšine základných škôl predstavujú iba 90 minút hrubého času pre pohyb detí, čo je v týždennom programe detí žalostne málo. Práve záujmová školská telesná výchova a šport otvára pre dorastajúcu a dospievajúcu mládež podstatne širšie možnosti ich pohybového a športového vyžitia, aktívneho a zmysluplného využitia vol’ného času.

K vytváraniu pozitívnych postojov $\mathrm{k}$ telesnej a športovej výchovy a k skvalitneniu realizácie záujmovej školskej telesnej výchovy a športu by pomohlo podl’a nášho názoru v súlade s odporúčaním Majerského et al. (2006) zavedenie do povinného úväzku učitel’a povinnej telesnej a športovej výchovy aj určitý počet hodín záujmovej telovýchovnej a športovej činnosti. Tak je to napríklad vo Francúzsku uvádza Sýkora (1995). Týmto krokom by sa nielen zvýšila úroveň športových záujmových krúžkov, ale súčasne by sa vytvoril v učitel'skej profesii priestor pre uplatnenie a realizáciu d’alších absolventov telovýchovného vysokoškolského štúdia v praxi. Zvýšila by sa aj kvalifikovanost' zamestnancov, prípadne učitelia telesnej a športovej výchovy by mohli získat' d’alší čiastočný úväzok a nemuseli by z existenčných dôvodov hl'adat' doplnkové zamestnanie v inej spoločenskej oblasti. Toto doplnkové zamestnanie mnohokrát nemá nič spoločné s telesnou výchovou a športom (podnikanie, poist'ovníctvo, ale $\mathrm{v}$ mnohých prípadoch aj manuálna a fyzicky náročná práca). Školská telesná výchova a šport by mali podobne ako vo Francúzsku ako uvádza Sýkora (1995) tvorit' podl'a nášho názoru aj na Slovensku dve vzájomne úzko súvisiace súčasti pôsobenia na výchovu, vzdelávanie a vývin žiakov. Sú to telesná a športová výchova ako povinný vyučovací predmet a záujmová športová činnost’ žiakov na školách.

;Zvyšujú sa aj nároky na učitel’ov telesnej a športovej, ktorí by mali vo väčšej miere uplatňovat' individuálny prístup, ovplyvňovat' záujem žiakov o svoje zdravie, správne ich motivovat' a viest' $\mathrm{k}$ individuálnej pohybovej aktivite mimo školy. Prioritou sa stáva vysoká profesionalita a osobný príklad. Zvýrazňuje sa požiadavka, aby telovýchovný pedagóg bol mládeži po celý svoj život vzorom, a to svojim výzorom, správaním a spôsobom života, čo robí túto profesiu vel'mi náročnou.

Učitel' v súlade so Štátnym vzdelávacím programom a najmä so Školským vzdelávacím programom školy, na ktorej vyučuje by si mal možnost' vybrat' na hodinách telesnej a športovej výchovy také pohybové a športové aktivity, ktoré by boli v súlade so záujmom väčšiny žiakov, objektovým a materiálovým vybavením školy, klimatickými podmienkami, skúsenost’ami učitel’a a pod.

\section{ZÁVERY}

1. Zistili sme, že u žiakov 4. ročníkov na základných školách v okrese Zvolen prevažujú prevažne pozitívne $(49,74 \%)$ a vel'mi pozitívne postoje $(32,19 \%) \mathrm{k}$ telesnej a športovej výchove nad postojmi indiferentnými $(16,45 \%)$. Negatívne postoje $(1,26 \%)$ a vel'mi negatívne postoje $(0,36 \%)$ žiaci prejavili iba ojedinele. 
2. Znepokojujúce je zistenie na vidieckych malotriednych základných školách v okrese Zvolen, kde žiaci

4. ročníkov prejavili iba $17,24 \%$ pozitívnych a 31,03 vel'mi pozitívnych postojov a až 44,84 indiferentných postojov a $6,89 \%$ negatívnych postojov $\mathrm{k}$ telesnej a športovej výchove.

3. Žiaci mestských ZŠ v okrese Zvolen (84,47 \%) prejavili o 3,67 \%viac pozitívnych a vel'mi pozitívnych postojov k telesnej a športovej výchove ako žiaci vidieckych ZŠ $(80,80 \%)$

4. Chlapci na mestských (88,95 \%) a vidieckych (84,31 \%) ZŠ v okrese Zvolen mali viac vel'mi pozitívnych a pozitívnych postojov $\mathrm{k}$ telesnej a športovej výchove ako dievčatá na mestských $(77,41 \%)$ a vidieckych Z $\breve{S}(73,32)$.

Uvedený výskum s touto tematikou by bolo vhodné do budúcnosti realizovat' aj v iných okresoch a častiach Slovenska a zmapovat' situáciu na väčšom území.

I ked' výsledky výskumu nemôžeme zovšeobecňovat' pre potreby praxe odporúčame:

1. Skvalitnit' výchovno - vzdelávací proces v telesnej a športovej výchove, zavádzat' netradičné a menej rozšírené pohybové a športové aktivity, modernizovat' obsah vyučovania, formy a metódy práce. V d'alšom období je dôležité zlepšit' aj priestorové a materiálne vybavenie škôl najmä na vidieckych malotriednych ZŠ. Toto vybavenie uvedených škôl pre potreby telesnej a športovej výchovy je na nedostatočnej úrovni.

2. Zvýšit’ časovú dotáciu vo všetkých ročníkoch na základných školách a stredných školách v rámci Rámcových učebných plánov Štátneho vzdelávacieho programu na minimálne 3 hodiny povinnej telesnej a športovej výchovy týždenne.

3. Motivovat žiakov školy $\mathrm{k}$ pravidelnému pohybu a športovaniu zarad’ovaním ich oblúbených pohybových a športových aktivít do obligatórnych a fakultatívnych foriem školskej telesnej výchovy a športu. Z uvedeného dôvodu taktiež odporúčame učitel'om telesnej a športovej výchovy pravidelne zist'ovat' štruktúru týchto športových a pohybových záujmov u žiakov.

4. Vzhl'adom $\mathrm{k}$ poklesu pozitívnych postojov k školskej telesnej výchove a športu najmä u žiakov vyšších ročníkov ZŠ snažit' sa viac zapojit' školskú mládež do pohybových a športových aktivít prostredníctvom športových krúžkov a sút'aží na školách. Zvýšit’ ponuku takýchto záujmových krúžkov najmä pre dievčatá a žiakov vyšších ročníkov na 2. stupni základných škôl.

5. Pre porovnatel'nost’ výskumov v rôznych častiach Slovenska odporúčame pri výskume postojov žiakov $\mathrm{k}$ telesnej a športovej výchove použivat’ štandardizované postojové dotazníky.

6. Pri príprave budúcich učitel'ov telesnej a športovej výchovy na vysokých školách odporúčame väčšiu hodinovú dotáciu netradičných športov a pohybových aktivít.

\section{Literatúra}

ANTALA, B. - DOROŠOVÁ, S. 1996. Postoje žiakov pohybovo podpriemerných a pohybovo na priemerných ku školskej telesnej výchove. Telesná výchova a šport. ISNN 1335-2245, 1996, roč. 6, č. 4., s. 8 - 10.

BARTÍK, P. 2005. Postoje žiakov 2. stupňa základnej školy k telesnej výchove. In Acta universitatis Matthaei Belii, Zborník vedeckovýskumných prác, č. 9. Banská Bystrica: UMB, 2005, ISBN 80-8083-161-0, s. 158 - 164. BARTÍK, P. 2006. Postoje žiakov 1. stupňa ZŠ k Telesnej výchove a pohybovým aktivitám v regióne Čadca. In Sborník referátú z 6. Medzinárodního vědeckého semináre „Efekty pohybového zatižení v edukačním prostřed itělesné výchovy a sportu “. Olomouc: FTK UP, 2006. ISBN 80-244-1366-3, s. 46.

BARTÍK, P. 2007a. Postoje žiakov k telesnej výchove na 1. stupni ZŠ na vybraných školách v Banskej Bystrici. In Telovýchovný proces na školách, Recenzovaný zborník vedecko - výskumných prác. Banská Bystrica: PF UMB v spolupráci s klubom TV UMB a Regionálnej pobočky SVSTV a Š v Banskej Bystrici, 2007a. ISBN 978-80-8083-501-9, s. 46-56.

BARTÍK, P. 2007b. Postoje žiakov 5. a 9. ročníkov na vybraných ZŠ k telesnej výchove. In Optimální působení tělesné záteže a výživy 2007 s podtitulem Kinantropologické dny MUDr. V. Soulka, Sborník příspevku ze XVI. Ročníku interdisciplinární konference s medzinárodni účastí. Hradec Králové: PF UHK, 2007b. ISBN 978-807041-513-9, s. 210 - 216.

BARTÍK, P. 2009a. Postoje žiakov základných škôl k telesnej výchove. In Exercitatio corpolis - motus salus. Banská Bystrica: FHV UMB, KTVaŠ, Vedecká spoločnost' pre TV a šport, 2009a. ISSN 1337-7310, s. $153-159$. 
BARTÍK, P. 2009b. Postoje žiakov základných škôl k telesnej výchove a športu a úroveň ich teoretických vedomostí z telesnej výchovy v intenciách vzdelávacieho štandardu. Banská Bystrica: FHV UMB Banská Bystrica, 2009b. 132 s. ISBN 978-80-8083-764-8.

BARTÍK, P., MESIARIK, P. 2009. Postoje žiakov deviateho ročníka základných škôl v stredoslovenskom regióne k školskej telesnej výchove a športu. In Telesná výchova a šport. ISSN 1335-2245, 2009, roč. 19, č. 1, s. 7-9.

BARTÍK, P., MESIARIK, P. 2011. Vplyv záujmovej školskej telesnej výchovy a športu na formovanie pozitívnych postojov žiakov k pohybovým aktivitám. In Exercitatio corpolis - motus - salus = Slovak journal of sports sciences: slovenský časopis o vedách o športe. Banská Bystrica: FHV UMB, 2011. ISSN 1337-7310, roč. 3, č. 1, s. 97-104.

BEBČÁKOVÁ, V. et al. 2009. Učebné osnovy z predmetu Telesná a športová výchova pre ISCED 2. In Športový edukátor, Nitra: KTVŠ PF Univerzita Konštantína Filozofa. ISSN 1337-7809, 2009, roč. II., č. 1, s. 4-28.

BOROŠ, J., ONDRIŠKOVÁ, E., ŽIVČICOVÁ, E. 1999. Psychológia. Bratislava: Iris, 1999. 270 s. ISBN 80-88778-87-5.

DOBRÝ, L. 2006. Souvislosti výkonu s duševním rústem mladých sportovců. In Tělesná výchova a sport mládeže. ISSN 0323-0449, 2006, roč. 72, č. 2, s. 18-24.

GÓRNA, K. 1997. Vztah chlapců a dívek středních škol olomouckého a katowického regionu k vyučovacím jednotkám tělesné výchovy. In Telesná výchova a sport mládeže. ISSN 0323-0449, 1997, roč. 63, č. 5, s. $41-43$.

GÓRNA, K. 1998. Deklarace zapojení do rekreační pohybové aktivity, vědomosti z oboru tělesné kultury a vlastní hodnocení pohybových dovedností studentů na gymnáziích. In Télesná výchova a šport. ISSN 1335-2245, 1998, roč. 8, č. 1, s. 14-18.

GÖRNER, K., STARŠÍ, Jaroslav. 2001. Postoje, vedomosti a názory žiakov II. stupňa ZŠ na telesnú výchovu. Banská Bystrica: UMB, Fakulta humanitných vied, 2001, 162 s. ISBN 80-8055-565-6.

HARTL, P. 2004. Stručný psychologický slovník. Praha: Portál, 2004. 311 s. ISBN 80-7178-803-1.

HERCIG, S. 2009. Telesná výchova ve školním vzdělávacím programu. In Telesná výchova a sport mládeže. ISSN 0323-0449, 2009, roč. 75, č. 1. s. 4 - 6.

KATUŠČÁK, D. 1998. Ako pisat'vysokoškolské a kvalifikačné práce. Bratislava: vydavatel'stvo STIMUL, 1998. 119 s. ISBN 80-85697-82-3.

KOSOVÁ, B., KASÁČOVÁ, B. Základné pojmy a vztahy v edukácií. Banská Bystrica: PdF UMB, 2009. 161 s. ISBN 978-80-83-525-5.

KUBÁNI, V. 2004. V̌̌eobecná psychológia. Prešov: FHPV PU Prešov, 2004. 90 s. ISBN 80-8868-257-7.

LÁSZLO, K. 2003. Ako písat'seminárne, záverečné a diplomové práce. Banská Bystrica: PF Univerzita Mateja Bela, 2003. 52 s. ISBN 80-8055-822-1.

LUDVIKOVÁ, M. 2010a. Attitudes of secondary school pupils to physical education and physical acticity in the region of Banská Bystrica. In Acta Universitatis Matthiae Belii : Physical education and sport. Vol. II., No. 1. Banská Bystrica : FHV UMB, 2010a. ISSN 1338-0974. s. 77-84.

LUDVIKOVÁ, M. 2010b. Postoje žiakov stredných škôl k telesnej výchove a pohybovým aktivitám v Banskobystrickom kraji. In Zborník referátov z fakultnej konferencie študentskej vedeckej aktivity. 1. vyd. Banská Bystrica: Univerzita Mateja Bela, Fakulta humanitných vied, 2010b. ISBN 978-80-8083-998-7. s. 1-9. LUDVIKOVÁ, M. 2010c. Postoje žiakov stredných škôl k telesnej výchove a pohybovým aktivitám v štáte Virginia v USA. In Pohybová aktivita v živote človeka - Pohyb detí. Zborník konferenčných recenzovaných vedeckých príspevkov. Prešov: Prešovská univerzita, 2010c. ISBN 978-80-555-0301-1. s.111-117.

MAJERSKÝ, O. et al. 2006. Podnety na inováciu učebných osnov telesnej výchovy na základných a stredných školách. Telesná výchova a šport. ISNN ISSN 1335-2245, 2006, roč. 16, č. 2, s. 2-6.

MESIARIK, P. 2009. Teoretické vedomosti žiakov 9. ročníka ZŠ a úroveň ich postojov k školskej telesnej výchove a športu v intenciách vzdelávacieho štandardu: rigorózna práca. Banská Bystrica: FHV UMB, KTVŠ, 2009. $99 \mathrm{~s}$.

MESIARIK, P. 2010. Golf - netradičný šport v záujmovej školskej TV a športe a jeden z prostriedkov formovania pozitívnych postojov $k$ školskej telesnej výchove a športu: rigorózna práca. Brno: FSpS MU, 2010. $143 \mathrm{~s}$.

MESIARIK, P. 2011. Attitudes of boys sport's football classe to physical education. In Acta Universitatis Matthiae Belii, Physical Education and Sport: Recenzovaný časopis vedeckých štúdií. Banská Bystrica: FHV 
UMB, 2011. ISSN 1338-0974, Vol. III., No. 2, s. 49-59.

MICHAL, J. 2002. Názory, postoje a vzt’ah študentov UMB k telesnej výchove, športu a pohybovým aktivitám. In Acta universitatis Matthaei Belii, Telesná výchova a šport, vol. 4, č. 4. Banská Bystrica: UMB, 2002. ISBN 80-8055-727-6, s. 50 - 55.

MICHAL, J. - KOLLÁR, R. - KRUŽLIAK, M. 2010. Názory a postoje študentov stredných škôl k pohybovým aktivitám, telesnej a športovej výchove. In Pohybová aktivita v živote človeka- Pohyb detí. Zborník recenzovaných vedeckých príspevkov. Prešov: Prešovská univerzita, 2010. ISBN 978-80-555-0301-1, s. $122-129$.

MIKUŠ, M., BEBČÁKOVÁ, V. et al. 2004. Pokyny na hodnotenie vzdelávacích štandardov z telesnej výchovy na 2. stupni základných škôl. Bratislava: Ministerstvo školstva Slovenskej republiky. 2004. 44 s.

MIKUŠ, M., BEBČÁKOVÁ, V., MODRÁK, M. 2008. K niektorým problémom realizácie nových učebných osnov v praxi. In Telesná výchova a šport, zdravie a pohyb. Prešov: PU v Prešove, 2008. ISBN 978-80-8045-515-6, s. 41 - 45.

NAKONEČNÝ, M. 1999. Sociálni psychologie. Praha: Academia, nakladatelství Akademie věd České republiky, 1999. 287 s. ISBN 80-200-0690-7.

PALIČKA, M. 2011a. Porovnanie zmien postojov žiakov 7. ročníkov na začiatku a na konci školského roka na základnej škole v regióne Spiš. In Acta Facultatis Humanisticae Universitatis Matthiae Belii Neosoliensis. Banská Bystrica: FHV UMB, 2011a. ISBN 978-80-557-0235-3, s. 101 - 106.

PALIČKA, M. 2011b. Vplyv školského vzdelávacieho programu na formovanie postojov žiakov základných škôl k telesnej a športovej výchove v regióne Spiš. In Zborník z vedeckej konferencie TU. Zvolen: Technická univerzita, Ústav telesnej výchovy a športu, Univerzitné centrum, 2011b. ISBN 978-80-228-2279-4, roč. 2, s. $205-211$.

PISTLOVÁ, L' - SEDLÁČEK, L'. 2008. Postoje študentov FTVŠ UK k pohybovým aktivitám. In Telesná výchova a šport. ISSN 1335-2245, 2008, roč. 18, č. 3-4, s. 8-12.

POLIACH, V. 2003. Základy psychológie osobnosti. Žilina: EDIS - vydavatel'stvo Žilinskej univerzity, 2003. 74 s. ISBN 80-8070-050-8.

RÝGL, P. 2003a. Neradostný pohled na tělesnou výchovu. In Telesná výchova a sport mládeže. ISSN 1210-7689, 2003a, roč. 69, č. 2, s. 43-46.

RÝGL, P. 2003b. Negramotnost v tělesné výchově. In Telesná výchova a sport mládeže. ISSN 1210-7689, 2003b, roč. 69, č. 3, s. 40 - 42.

SEKOT, A. 2007a. Sociologické dimenze sportu. In Studia sportiva, Brno: FSpS, Masarykova univerzita. ISSN 1211-9261, 2007, č. 1, s. 66-75.

SEKOT, A. 2007b. Sport jako významný faktor socializace. In Studia sportiva, Brno: FSpS, Masarykova univerzita. ISSN 1211-9261, 2007b, č. 1, s. 107-114.

SIVÁK, J. et al. 2000. Vzdelávací štandard z telesnej výchovy pre 2. stupeň základných škôl. Bratislava: MŠ SR, 2000. $31 \mathrm{~s}$.

SIVÁK, J., KRŠJAKOVÁ, S., SOKOL, P. 2001. Metodická príručka $k$ vzdelávaciemu štandardu z TV pre 1. stupeň ZŠ. Bratislava: Perfekt, 2001. 37 s. ISBN 80-8046-123-6.

STARŠÍ, J. 1999. Vedy o športe. FHV UMB Banská Bystrica, 1999. 77 s. ISBN 80 - 8055-321 - 2.

STARŠÍ, J. - GÖRNER, K. 1995. Vedeckovýskumná činnost’v telesnej výchove a športe. FHV UMB Banská Bystrica, 1995. 83 s. ISBN 80 - 8055-565 - 6.

SÝKORA, F. Školská telesná výchova a šport vo Francúzsku. Telesná výchova a šport. ISSN 1335-2245,1995, roč. 5, č. 4, s. 2-6.

SUBRAMANIAN, P. R. - SILVERMAN, S. 2007. Elektronické zdroje: Middle schol studen's attitudes toward physical education. In: Teaching and Teacher Education, vol. 23, 2007 [cit. 24.11.2010], s. 602 - 611. Dostupné na internete:

http://www.sciencedirect.com/science?_ob=ShoppingCartURL\&method=add\&_udi=B6VD84NDDT062\&_acct $=$ C000050221\&_version $=1 \&$ userid $=10 \&$ ts $=1302802977 \& \mathrm{md} 5=\mathrm{a} 34 \mathrm{c} 79175136 \mathrm{c} 4 \mathrm{eb} 2 \mathrm{cc} 6 \mathrm{~b} 1 \mathrm{~d} 1 \mathrm{ed} 5670 \overline{\mathrm{f}} \mathrm{f}$

STELZER, J. - ERNEST, J. M. - FENSTER, M. J. - LANGFORD, G. 2004. Elektronické zdroje: Attitudes toward physical education: a study of high schol students from four countries Austria, Czech republic, England and USA. In: College Student Journal, jun,

2004 [cit.03.12.2011]. Dostupné na internete:

http://findarticles.com/p/articles/mi_m0FCR/is_2_38/ai_n6124562/pg_2/?tag=content;co11 
ŠIKULA, T. 1992. Názory a postoje študentov Právnickej fakulty UK na výučbu telesnej výchovy v nových podmienkach štúdia za roky 1989 - 1990 a 1990 - 1991. In Telesná výchova a šport. ISSN 1335-2245, 1992, roč. 2 , č. 3, s. $8-12$.

ŠIMONEK, J. 2010. Materiálno - technické a personálne zabezpečenie vyučovania telesnej a športovej výchovy v slovenských základných školách. In Telesná výchova a šport. ISSN 1335-2245, 2010, roč. 20, č. 4, s. 19-23.

ŠVEC, Š. et al. 1998. Metodológia vied o výchove. Bratislava: IRIS, 1998. 303 s.ISBN 80-88778-73-5.

VLADOVIČOVÁ, N. - NOVOTNÁ, N. 2005. Športové záujmy rómskych žiakov 1. stupňa základnej školy. In Acta universitatis Matthaei Belii, Zborník vedeckovýskumných prác, č. 9. Banská Bystrica: UMB, 2005. ISBN 80-8083-161-0, s. 173 - 179.

Zákon o výchove a vzdelávaní (školský zákon) č. 245/2008

ZICH, F., UNGR, V. 1995. Postoje české veřejnosti k tělesné výchově a sportu. In Telesná výchova a sport mládeže. ISSN 0323-0449,1995, roč. 61, č. 3, s. 1-8.

\section{Príloha - Postojový dotazník z telesnej výchovy pre žiakov 4. ročníka ZŠ}

(Zdroj: Sivák, J. - Kršjaková, S. - Sokol, P. Metodická príručka k vzdelávaciemu štandardu z TV pre 1. stupeň ZŠ (2001) odporúčaný Ministerstvom školstva Slovenskej republiky).

Milý žiak, žiačka,

dostal (a) si do rúk dotazník, ktorým chceme zistit’, čo si myslís o školskej telesnej výchove a športe. Aj Tvoje odpovede nám pomôžu urobit’ také zmeny, aby tento predmet bol pre žiakov zaujímavejší a oblúbenejší.

Za Tvoju snahu, ochotu a úprimné odpovede Ti vopred d’akujeme.

Pri vyplňovaní dotazníka postupuj takto:

1. Najprv si viackrát prečítaj jednotlivé vety.

2. Po prečítaní porozmýšlaj a podčiarkni jednu z možností:

- $\quad$ ak s tým, čo si prečítal (a) súhlasíšs, podčiarkni áno,

- $\quad$ ak s tým, čo si prečítal (a) nesúhlasíšs, podčiarkni nie,

- $\quad$ ak sa nevieš rozhodnút', alebo nevieš odpovedat', podčiarkni bud' neviem, prípadne ak to konštrukcia odpovede dovol'uje napíš bud' niekedy áno, alebo niekedy nie.

\section{Prosím vyplň!!!}

Názov školy:

Chlapec

\section{Ročník:}

\section{Dievča}

1. Žiaci by mali mat' telesnú výchovu každý deň.

áno nie neviem

2. Cvičit' potrebujú žiaci, ktorí chcú byt' športovcami.

áno nie neviem

3. Cvičit' treba hlavne preto, aby sme boli zdravší.

áno nie neviem

4. Upevnit' zdravie sa dá i bez cvičenia.

áno nie neviem

5. Telesná výchova je zbytočné unavovanie tela 
áno nie neviem

6. Cvičit' je pre žiakov rovnako dôležité, ako učit' sa čítat', písat', počítat'.
áno
nie
neviem

7. Ked'sa na telesnej výchove naučím nové cvičenia, mám z toho vždy vel'kú radost'.

áno nie neviem

8. I ked’ som po telesnej výchove unavený (á), nevadí mi to a mám z toho príjemný pocit.
áno
nie
niekedy áno
niekedy nie

9. Ak na hodine telesnej výchovy nemôžem cvičit', alebo ak nám odpadne hodina telesnej výchovy je mi to vždy vel'mi l'úto.

áno nie niekedy áno niekedy nie

10. Z $\quad \mathrm{Z}$ cvičenia na hodinách telesnej výchovy mám skoro vždy strach.
áno
nie
niekedy áno
niekedy nie

11. Telesná výchova je mojim najoblúbenejším predmetom.
áno
nie
neviem

12. Na hodiny telesnej výchovy sa teším hlavne preto, lebo pri cvičení sa môžem vybehat' i zasmiat' bez toho, aby nás učitel' upozorňoval, že vyrušujeme.
áno
nie
niekedy áno
niekedy nie

13. Vel’mi rád pomáham doma, chodím na nákupy, vynášam smeti.
áno
nie
niekedy áno
niekedy nie

14. Rád organizujem rôzne hry (naháňačky, schovávačky, skákanie cez gumu a iné) i pre kamarátov kamarátky.

áno nie niekedy áno niekedy nie

15. Svoj vol'ný čas najradšej využívam na bicyklovanie, na hry s loptou, na sánkovanie.
áno
nie
niekedy áno
niekedy nie

16. Vol’ný čas využívam radšej na čítanie, ale i na pozeranie televízie.
áno
nie
niekedy áno
niekedy nie

17. Vel'mi sa teším na tie soboty a nedele, na ktoré plánujú rodičia výlet do prírody.

18. Ked' je zlé počasie, cvičím i doma v byte.

niekedy áno niekedy nie

áno nie niekedy áno niekedy nie 